\title{
Cooperative regulation of endogenous cAMP-response element binding protein and CCAAT/enhancer-binding protein $\beta$ in GH-stimulated c-fos expression
}

\author{
Tracy Xiao Cui, Roland Kwok ${ }^{1}$ and Jessica Schwartz \\ Department of Molecular and Integrative Physiology, University of Michigan, Ann Arbor, Michigan 48109-0622, USA \\ ${ }^{1}$ Departments of OB/GYN and Biological Chemistry, University of Michigan, Ann Arbor, Michigan 48109, USA \\ (Correspondence should be addressed to J Schwartz; Email: jeschwar@umich.edu)
}

\begin{abstract}
$\mathrm{GH}$ activates the c-fos promoter by regulating multiple transcription factors. This study adds to our understanding of $\mathrm{GH}$-regulated transcription by demonstrating that $\mathrm{GH}$ regulates the c-fos cAMP-response element (CRE) and its binding protein, CREB. Activation of the c-fos promoter by $\mathrm{GH}$ is impaired by expression of dominant-negative A-CREB. GH stimulates rapid and transient phosphorylation of CREB at Ser 133 (P-CREB), a critical site for transactivation by CREB, in 3T3-F442A preadipocytes. Mutation of this residue impairs $\mathrm{GH}$-induced c-fos expression, suggesting that phosphorylation of CREB at Ser 133 contributes to GH-induced c-fos activation. The MEK inhibitor UO126 impaired the phosphorylation of CREB and that of $\mathrm{C} / \mathrm{EBP} \beta$, suggesting that ERKs mediate the phosphorylation of both proteins. UO126, but not the protein kinase A inhibitor H89, blocked GH-induced c-fos mRNA
\end{abstract}

expression. A combination of CREB and C/EBP $\beta$ enhanced c-fos promoter activation, and mutation of the CRE impaired the enhancement, as well as GH-stimulated c-fos activation. GH treatment increased the occupancy of both endogenous phospho-CREB and phospho-C/EBP $\beta$ on the $\mathrm{c}-$ fos promoter. The increases were impaired by UO126. The active P-CREB and $\mathrm{P}-\mathrm{C} / \mathrm{EBP} \beta$ are induced by $\mathrm{GH}$ to occupy the same c-fos promoter DNA, suggesting that they may participate in a $\mathrm{GH}$-regulated complex on c-fos. These findings suggest that coordinated phosphorylation of CREB and C/EBP $\beta$ in response to $\mathrm{GH}$ is mediated by $\mathrm{ERK} 1 / 2$, and that the phosphorylated proteins are part of a regulatory complex that occupies c-fos in vivo to regulate c-fos transcription cooperatively in response to $\mathrm{GH}$.

Journal of Endocrinology (2008) 196, 89-100

\section{Introduction}

Growth hormone $(\mathrm{GH})$ is a major regulator of growth and metabolism and regulates the transcription of numerous genes (Tollet-Egnell et al. 2004, Rowland et al. 2005, Huo et al. 2006). The proto-oncogene c-fos, which participates in cellular proliferation and differentiation (Holt et al. 1986, Nishikura \& Murray 1987), is rapidly and transiently induced by GH (Doglio et al. 1989, Gurland et al. 1990) as well as by other stimuli. Analysis of $\mathrm{c}-$ fos provides a model for understanding mechanisms of GH-regulated gene transcription (Cesena et al. 2007). The c-fos promoter contains multiple GH-responsive enhancer elements (Fig. 1A), including the sis-inducible element (SIE), serum-response element (SRE) and an adjacent CCAAT/ enhancer-binding protein (C/EBP) site, and an activator protein-1 (AP-1) site; these elements can be bound by cognate transcription factors to regulate c-fos transcription in response to GH (Meyer et al. 1993, 1994, Gronowski \& Rotwein 1994, Chen et al. 1995, Clarkson et al. 1995, Gronowski et al. 1995, 1996, Liao et al. 1997, 1999, Hodge et al. 1998).

A highly conserved cAMP-response element (CRE) located $\sim 60$ bps upstream of the transcription start site of $\mathrm{c}-$ fos (Fig. 1A) binds the CRE-binding protein (CREB), and related activating transcription factor (ATF) family proteins (Sheng et al. 1988, Fisch et al. 1989); mutation of the CRE prevents CREB binding (Berkowitz et al. 1989). CREB occupies the c-fos promoter constitutively, as detected by chromatin immunoprecipitation (ChIP; Fass et al. 2003, Cha-Molstad et al. 2004). Transactivation by CREB generally depends upon its phosphorylation at the critical Ser 133 (P-CREB; Shaywitz \& Greenberg 1999, Mayr \& Montminy 2001, Quinn 2002, Servillo et al. 2002). Protein kinase A (PKA) mediates Ser 133 phosphorylation of CREB which then binds to the CRE to mediate c-fos promoter activation (Gonzalez \& Montminy 1989, Boutillier et al. 1992). Numerous other kinases can also promote phosphorylation of CREB at Ser 133, including calcium-calmodulin-dependent kinases, protein kinase $\mathrm{C}$, and MAP kinase (MAPK) pathway members, such as $\mathrm{pp} 90^{\mathrm{Rsk}}$, mitogen- and stress-activated protein kinase, and p38 (Shaywitz \& Greenberg 1999, Mayr \& Montminy 2001).

To date, the CRE and CREB have not been implicated in $\mathrm{GH}$-induced c-fos expression. However, GH has been reported to induce the phosphorylation of CREB at S133 in 3T3-F442A preadipocytes (Yarwood et al. 1998). 
Analysis of c-Fos expression in vivo indicated that the CRE acts interdependently with the SIE, SRE, and AP-1 sites to mediate its endogenous expression (Robertson et al. 1995). These observations suggest that the CRE and the CREB contribute to $\mathrm{GH}$-stimulated c-fos expression; such a role is documented herein.

Among the transcription factors that mediate GH-stimulated $c-f o s$ expression, $\mathrm{C} / \mathrm{EBP} \beta$ appears to be critical (Clarkson et al. 1995, Liao et al. 1999). Depletion of $\mathrm{C} / \mathrm{EBP} \beta$ by RNA interference abolishes the ability of $\mathrm{GH}$ to stimulate expression of endogenous c-fos mRNA and c-fos promoter activation (Cui et al. 2005). The phosphorylation of $\mathrm{C} / \mathrm{EBP} \beta$, like that of $\mathrm{CREB}$, contributes to its ability to activate transcription. For $\mathrm{C} / \mathrm{EBP} \beta$, an activating phosphorylation is mediated by a mechanism involving activation of the MAPK extracellular signal-regulated kinases 1 and 2 (ERK1/2), which leads to phosphorylation of murine $\mathrm{C} / \mathrm{EBP} \beta$ at $\mathrm{Thr} 188$ (equivalent to $\mathrm{T} 235$ in human $\mathrm{C} / \mathrm{EBP} \beta) . \mathrm{C} / \mathrm{EBP} \beta$ phosphorylation at T188 (P-C/EBP $\beta$ ) is required for activation of $\mathrm{c}-f \circ$ in response to $\mathrm{GH}$ (Piwien-Pilipuk et al. 2002, 2003). Since MAPKs can also phosphorylate and activate CREB (Shaywitz \& Greenberg 1999), the activation of ERK1/2 by GH suggested that their ability to mediate phosphorylation of CREB and C/EBP $\beta$ might play a role in coordinating their participation in $\mathrm{c}-f \circ s$ activation by $\mathrm{GH}$.

Gene regulation is recognized to involve regulatory complexes containing multiple factors that occupy target gene promoters and cooperatively regulate gene transcription (Merika \& Thanos 2001, Cosma 2002). C/EBP $\beta$ associates with other $\mathrm{GH}$-regulated nuclear proteins, such as serumresponse factor and Elk-1 that bind to the c-fos SRE; this association can increase c-fos promoter activation in a Ras-dependent manner (Treisman 1994, Hanlon et al. 2000, 2001). C/EBP $\beta$ has also been identified to be part of a complex containing the co-activator p300 that occupies c-fosin vivo, in response to $\mathrm{GH}$, and p300 enhances C/EBPmediated c-fos expression (Cui et al. 2005). Thus, GH-regulated $c$-fos transcription appears to involve the formation of complexes containing $\mathrm{C} / \mathrm{EBP} \beta$ and other factors on the $\mathrm{c}-f \circ$ s promoter. Although CREB has not previously been implicated in GH-regulated transcription, it is well established that CREB participates in transcription complexes which often contain CREB-binding protein (CBP), and are detected on sequences throughout the genome (Impey et al. 2004, Zhang et al. 2005).

The present study demonstrates that CREB contributes to GH-regulated c-fos activation. CREB can cooperate with $\mathrm{C} / \mathrm{EBP} \beta$, another $\mathrm{GH}$-regulated transcription factor which activates $c-f o s$ to enhance transcription. In response to $\mathrm{GH}$, both $\mathrm{CREB}$ and $\mathrm{C} / \mathrm{EBP} \beta$ are phosphorylated by mechanisms involving activation of ERK1/2. The endogenous activated $\mathrm{P}-\mathrm{CREB}$ and $\mathrm{P}-\mathrm{C} / \mathrm{EBP} \beta$ are induced to occupy the same $\mathrm{c}$-fos promoter DNA in response to $\mathrm{GH}$. These findings suggest that phosphorylated CREB and C/EBP $\beta$ may be part of a regulatory complex, coordinated by activation of
ERK1/2, and that they occupy $c$-fos and regulate its transcription cooperatively in response to $\mathrm{GH}$.

\section{Materials and Methods}

\section{Materials}

Murine 3T3-F442A preadipocytes were provided by H Green (Harvard University) and M Sonenberg (Sloan-Kettering, NY, USA). Chinese hamster ovary (CHO) cells stably expressing a truncated $\mathrm{GH}$ receptor (GHR1-454) were provided by $\mathrm{G}$ Norstedt (Karolinska Inst., Sweden) and N Billestrup (Novo Nordisk, Gentofte, Denmark; Moller et al. 1992); they are designated CHO-GHR cells and were used as described (Gong et al. 1998, Piwien-Pilipuk et al. 2001, Cui et al. 2005). Human $\mathrm{GH}$ was generously provided by Eli Lilly Inc. Culture media, fetal calf serum, L-glutamine, and antibiotic-antimycotic were purchased from Invitrogen, and calf serum from Invitrogen or from Atlanta Biologicals. BSA (CRG7) was purchased from Serologicals Corp., MEK inhibitor UO126 from Promega, and PKA inhibitor H89 from Calbiochem. Protease inhibitor cocktail tablets (EDTA free) and the protease inhibitors leupeptin and aprotinin were purchased from Roche, phenylmethylsulfonyl fluoride (PMSF) from Mallinckrodt, sodium orthovanadate and formaldehyde from Sigma, immobilized protein A from Repligen, protein $G$ beads from Amersham, sonicated salmon sperm DNA from Stratagene, and the PCR Purification Kit from Qiagen. Immobilon-P transfer membrane (pore size $0.45 \mu \mathrm{m}$ ) was purchased from Millipore, the ECL Western Blotting Detection Reagents from Amersham, protein molecular weight standards from Invitrogen and Santa Cruz Biotechnology (Santa Cruz, CA, USA), RNA STAT-60 from Tel-Test B Inc., TaqMan Reverse Transcription Kit from Applied Biosystems (Foster City, CA, USA), SYBR Green I from Sigma, luciferin from Promega, and $\beta$-galactosidase chemiluminescence reagents from Tropix.

\section{Plasmids and antibodies}

The expression plasmids for an N-terminally FLAG-tagged CREB and for a similarly tagged mutant CREB with Ser 133 mutated to Ala (S133A) were described previously (Chrivia et al. 1993). The expression plasmid for A-CREB was kindly provided by C Vinson (NCI; Ahn et al. 1998). The expression plasmid for rat $\mathrm{C} / \mathrm{EBP} \beta$ was a gift from $U$ Schibler (University of Geneva, Geneva, Switzerland). The reporter plasmids fos-Luc wild-type (WT) containing the mouse c-fos enhancer $(-379$ to +1 , referred to as 'promoter' throughout) upstream of the luciferase gene, and fos-Luc mutated at the CRE (mCRE: CTCAGCTAG mutated residues underlined, Fig. 1A; Berkowitz et al. 1989) were generously provided by B Cochran (Tufts University). The vector pcDNA3 (Invitrogen) was used as a control. The plasmid CMV- $\beta$-galactosidase ( $\beta$-gal) was provided by $M$ Uhler (University of Michigan). 
The antibody against CREB (06-863) was purchased from Upstate. Antibody against CREB phosphorylated at Ser 133 (anti-P-CREB) of rabbit (06-519) or mouse origin was from Upstate or Cell Signaling respectively, an antibody against the $\mathrm{C}$-terminus of C/EBP $\beta$ was from Santa Cruz, the anti-P$\mathrm{C} / \mathrm{EBP} \beta$ antibody against murine $\mathrm{C} / \mathrm{EBP} \beta$ phosphorylated at T188 (equivalent to T235 of human $\mathrm{C} / \mathrm{EBP} \beta$ ) was from Cell Signaling, antibody against Fos, NFאB, and normal rabbit IgG were from Santa Cruz, antibody against RNA polymerase II phosphorylated at Ser 5 in the C-terminal domain (YSPT[pS]PS; anti-P-Pol II, 05-623) was from Upstate, the antibodies against Thr 202/Tyr 204 of human p44/42 MAP kinase (ERK1/2) and total p44/42 MAP kinases (ERK1/2) were from Cell Signaling, anti-FLAG antibody was from Sigma, and horseradish peroxidase-conjugated secondary antibodies for western blots were from Amersham or Santa Cruz. The secondary antibody conjugated with IRDye800, which was used in western blots scanned by Odyssey, was obtained from Rockland Inc.

\section{Cell culture and treatment}

3T3-F442A preadipocytes expressing endogenous GHR and CHO-GHR cells expressing exogenous GHR were grown and maintained as described previously (Cui et al. 2005). Cells were treated without or with human GH (500 ng/ $\mathrm{ml}=22 \mathrm{nM})$ or with forskolin $(30 \mu \mathrm{M})$ for the times indicated. In some experiments, 3T3-F442A cells were pre-treated with UO126 $(10$ or $20 \mu \mathrm{M})$ for $30 \mathrm{~min}$, or H89 $(20 \mu \mathrm{M})$ for $4 \mathrm{~h}$. Controls were treated with equivalent amounts of dimethyl sulfoxide (DMSO) vehicle $(0 \cdot 1 \% \mathrm{v} / \mathrm{v})$ for equivalent times. Prior to treatments, cells were deprived of serum for $18 \mathrm{~h}$ in the appropriate medium containing 1\% BSA instead of serum.

\section{Gene transcription assay}

Activation of the c-fos promoter was tested in GH-responsive CHO-GHR cells, in which the truncated GHR mediates c-fos transcription as efficiently as full-length GHR (Gong et al. 1998). The cells were transiently transfected using calcium phosphate co-precipitation as described (Piwien-Pilipuk et al. 2001, Cui et al. 2005) along with the fos-Luc reporter plasmids either wildtype or mCRE mutant $(0.5 \mu \mathrm{g}$ each), and with plasmids for A-CREB or control vector ( $5 \mu$ g each). CMV- $\beta$-gal (10 ng) was co-expressed as a control for transfection efficiency. After $24 \mathrm{~h}$, cells were incubated in F12 medium containing 1\% BSA for $18 \mathrm{~h}$ and then treated with $\mathrm{GH}$ or vehicle for $4 \mathrm{~h}$. Cells were lysed and the luciferase and $\beta$-galactosidase activities in the cell lysates were measured using an Opticomp Luminometer as described previously (Liao et al. 1999, Piwien-Pilipuk et al. 2001). Luciferase activity, which is normalized using $\beta$-galactosidase activity, is shown in relative luciferase units (RLUs). The basal c-fos promoter activation (set to 1) was measured in the absence of GH and/or in the presence of vector DNA. Luciferase activity is presented as mean \pm S.E.M. for at least three independent experiments, each performed in triplicate. Statistical analysis of increases due to either $\mathrm{GH}$ treatment or overexpressed gene was performed using one-way ANOVA with Bonferroni's multiple comparison test (Prism version 3, www.GraphPad.com). Statistical significance $(P<0 \cdot 05)$ is indicated in figures and figure legends by asterisks.

\section{Quantitative real-time PCR (QT-PCR)}

QT-PCR was performed on total RNA isolated from 3T3-F442A or CHO-GHR cells and analyzed using iCycler iQ real-time detection system software (Bio-Rad Laboratories) as described to amplify mouse c-fos and control GAPDH genes (Cui et al. 2005, Huo et al. 2006). Values for c-fos were normalized to GAPDH. When inhibitors were used, basal c-fos expression (set to 1) was measured in cells treated with DMSO. In some experiments, CHO-GHR cells were transiently transfected with plasmids for CREB, S133A-CREB, or pcDNA3 vector $(5 \mu \mathrm{g}$ each). After $24 \mathrm{~h}$, cells were incubated in F12 medium containing 1\% BSA for $18 \mathrm{~h}$, then treated without or with GH for $30 \mathrm{~min}$, and total RNA was prepared for QT-PCR. Statistical analysis was performed using one-way ANOVA with Bonferroni's multiple comparison test as described.

\section{Immunoblotting analysis}

Nuclear extracts from 3T3-F442A or CHO-GHR cells were prepared as described (Sadowski \& Gilman 1993, Liao et al. 1997) with several modifications. In some experiments, the plasmid DNAs for WT-CREB, A-CREB, S133A-CREB, or pcDNA3 (10 $\mu \mathrm{g}$ each) were expressed in CHO-GHR cells. To prepare the nuclear extracts, cells were lysed in buffer A (20 mM HEPES, $\mathrm{pH}$ 7·9, $1 \mathrm{mM}$ EDTA, $1 \mathrm{mM}$ EGTA, and 0·2\% NP-40) containing protease inhibitor cocktail for $10 \mathrm{~min}$ on ice followed by centrifugation $\left(16000 \mathrm{~g}, 30 \mathrm{~s}\right.$ at $\left.4{ }^{\circ} \mathrm{C}\right)$. Then, the nuclear pellet was dissolved in buffer $\mathrm{B}(60 \mathrm{mM}$ Tris- $\mathrm{HCl}, \mathrm{pH} 6 \cdot 8,1 \%$ SDS $)$ and was boiled for $10 \mathrm{~min}$. The nuclear extracts $(30 \mu \mathrm{g}$ each) were separated by SDS-PAGE (10\%) and transferred to PVDF membrane. Immunoblotting for endogenous or expressed protein was performed at $4{ }^{\circ} \mathrm{C}$ overnight as described (Liao et al. 1997) with the following antibodies: anti-P-CREB (1:1000), anti-CREB (1:1000), anti-P-C/EBP $\beta$ (T188; 1:1000), anti-C/EBP $\beta$ (1:1000), anti-NFKB (1:1000), anti-fos (1:1000), anti-P-ERK1/2 (1:2000), anti-ERK1/2 (1:1000), or anti-FLAG (1:1000). The proteins were visualized using ECL (Amersham) or the Odyssey scanning system (LI-COR Biosciences; Figs 1B and C, 2C, D and F; Cui et al. 2005). Molecular weight was estimated using MagicMark Western Standard (Invitrogen) or Cruz Marker Molecular Weight Standard (Santa Cruz).

\section{ChIP and re-ChIP}

ChIP was carried out as described (Cui et al. 2005). In some experiments, 3T3-F442A preadipocytes were pre-treated with UO126 $(20 \mu \mathrm{M})$ or with an equivalent amount of DMSO vehicle $(0 \cdot 1 \%, \mathrm{v} / \mathrm{v})$ for $30 \mathrm{~min}$ and were then treated with $\mathrm{GH}$ 

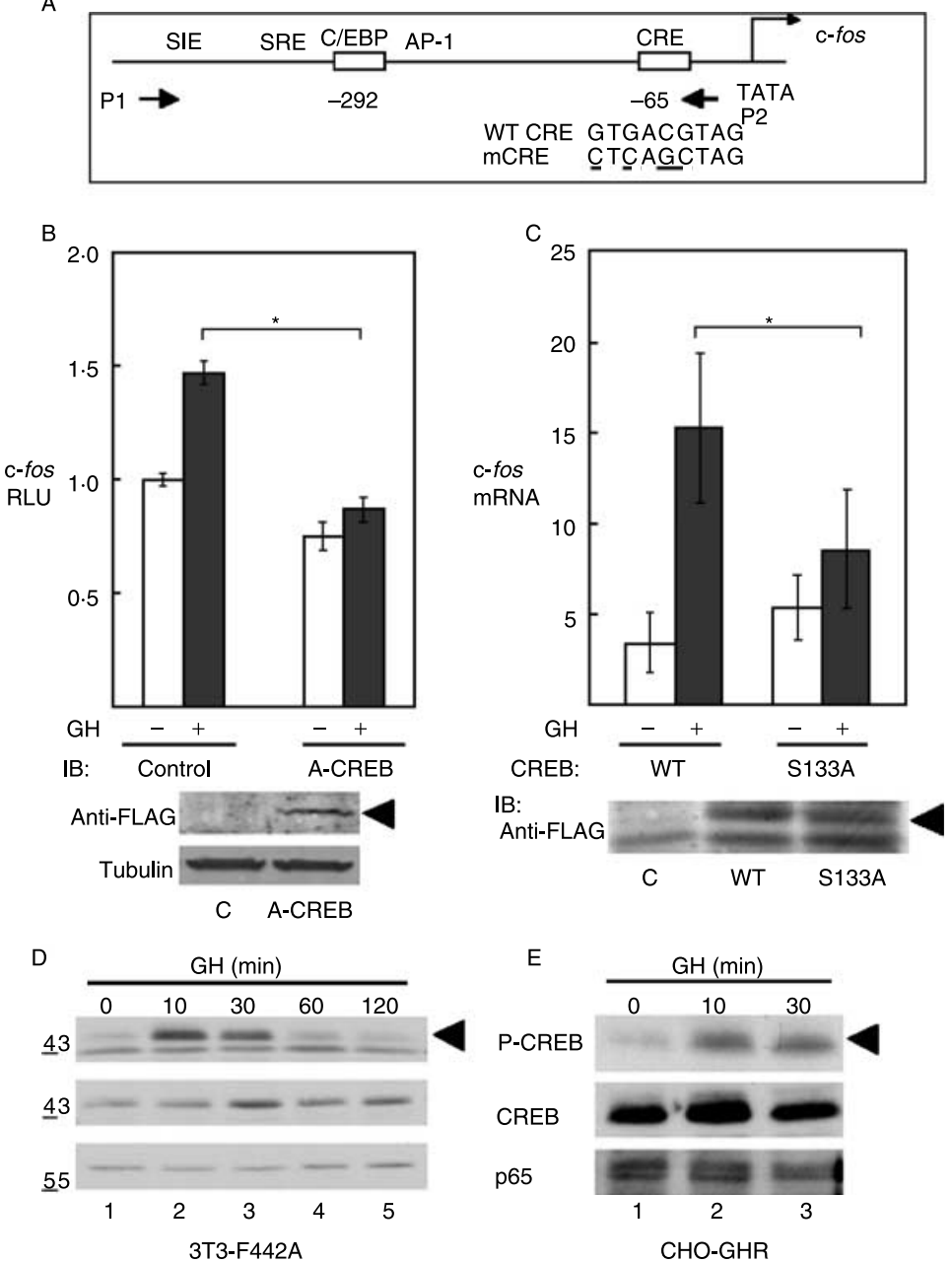

Figure 1 Phosphorylated CREB participates in GH-stimulated c-fos expression. (A) Schematic of the murine c-fos enhancer (not drawn to scale) shows multiple elements regulated by $\mathrm{GH}$, including a CRE and a C/EBP site. Sequences of wild-type (WT) CRE or mutant CRE (mCRE) are shown with mutations underlined. The arrows $\mathrm{P} 1$ and $\mathrm{P} 2$ indicate the primers that were used in ChIP PCR to amplify a single fragment of the murine c-fos promoter ( -364 to $-34 \mathrm{bp}$ ). (B) A-CREB or pcDNA3 (control; $10 \mu \mathrm{g}$ each) was co-expressed with fos-Luc $(0.5 \mu \mathrm{g})$ and $\beta$-gal $(0 \cdot 1 \mu \mathrm{g})$ in $\mathrm{CHO}-G H R$ cells. Cells were then treated with $\mathrm{GH}$ for $4 \mathrm{~h}$, and luciferase activity was measured ( $n=3$ independent experiments). Luciferase activity in cell lysates (RLU) is presented as mean \pm S.E.M. in this and subsequent figures. The increase in C-fos promoter activation due to $\mathrm{GH}$, which is highly reproducible although somewhat modest relative to serum (Gurland et al. 1990, Ashcom et al. 1992, Meyer et al. 1993), is significantly $(P<0 \cdot 05)$ reduced when A-CREB is expressed. Lower panel: immunoblotting indicates the expression of FLAG-tagged A-CREB in CHO-GHR cells (arrowhead). Tubulin indicates loading. Similar results were obtained in two experiments. (C) Plasmids for WT CREB or S133A-CREB ( $1 \mu \mathrm{g}$ each) were expressed in CHO-GHR cells. Cells were treated without (open bars) or with $\mathrm{GH}$ (black bars) for $30 \mathrm{~min}$. Total RNA was prepared and analyzed by QT-PCR for c-fos expression. Results are expressed as mean \pm s.E.M. relative to vector alone (set to 1 , not shown; $n=3)$. GH significantly $(P<0 \cdot 05)$ increases c-fos mRNA expression in the presence of wild-type CREB. However, GH-stimulated c-fos mRNA expression was significantly $(P<0 \cdot 05)$ reduced in the presence of the non-phosphorylatable mutant S133ACREB. Lower panel: the same plasmids for FLAG-tagged WT CREB, FLAG-tagged S133A-CREB, or pcDNA3 (control) were expressed in CHO-GHR cells (10 $\mu \mathrm{g}$ each). Nuclear extracts were analyzed by immunoblotting with anti-FLAG. The arrowhead indicates the FLAG-tagged CREB or S133A-CREB. A faster migrating non-specific band indicates loading. ( $D$ and E) Murine 3T3-F442A preadipocytes or E. CHO-GHR cells were treated with $\mathrm{GH}$ for the times indicated. Nuclear extracts were analyzed by immunoblotting with anti-P-CREB (top) or anti-CREB (middle). The bottom panel shows NFאB (p65) to indicate loading. Similar experiments were obtained in at least two experiments. 
for $15 \mathrm{~min}$. The nuclear extracts prepared from the cells were used for ChIP. In each immunoprecipitation, $100 \mu \mathrm{g}$ nuclear protein were incubated overnight at $4{ }^{\circ} \mathrm{C}$ with $4 \mu \mathrm{g}$ of one of the following antibodies: anti-CREB, anti-P-CREB, anti-C/ EBP $\beta$, anti-P-C/EBP $\beta$, or anti-P-Pol II. Samples incubated without antibody or normal rabbit IgG served as a negative control. One percentage of input was used to indicate the relative amount of each sample used for individual ChIP analysis. A single $330 \mathrm{bp}$ fragment $(-364$ to $-34 \mathrm{bp})$ of the mouse c-fos promoter encompassing the SIE, SRE, C/EBP site, and CRE (Fig. 1A, P1, and P2) was amplified as described (Cui et al. 2005). The $5^{\prime}$ distal region of mouse $c$-fos promoter ( -1692 to $-1436 \mathrm{bp}$ ) was amplified as a negative control for the c-fos promoter using the primers $5^{\prime}$-CAGGGAGGCAGAGGTTCCTAG- $3^{\prime}$ and $5^{\prime}$-CATTCCAAGACGGACTAGAGAG-3'. Transcription factors CREB, C/EBP $\beta$, and P-Pol II, which can be immunoprecipitated with $c$-fos promoter DNA but not with DNA from the $5^{\prime}$ distal region of $c-f o s$ (see Supplementary Fig. S1 in the online of version of the Journal of Endocrinology at http://joe.endocrinology-journals.org/ content/vol96/issue1/), supporting the specificity of the occupancy on the c-fos promoter by these proteins. In each experiment, all of the immunoprecipitated samples were analyzed using the same PCR conditions to evaluate relative amounts of each protein associated with the promoter. PCR products were separated on $2 \%$ agarose gels and stained with ethidium bromide. Bands were analyzed using Quantity One and Multi-Analyst software (Bio-Rad). Data, expressed as ratios of $\mathrm{GH} /$ control (C), for multiple experiments were presented as mean \pm s.E.M. and were analyzed using Student's $t$-test (Prism version 3). The reduction by UO126 relative to DMSO was calculated from the ratio UO126/DMSO.

re-ChIP was performed as described (Cui et al. 2005) with the following modifications: after the first ChIP, the beads were eluted with $100 \mu \mathrm{l} \mathrm{ChIP} \mathrm{SDS} \mathrm{lysis} \mathrm{buffer} \mathrm{(50} \mathrm{mM} \mathrm{Tris-HCl,} \mathrm{pH}$ $8,10 \mathrm{mM}$ EDTA, and 1\% SDS) containing protease inhibitors (1 mM each of sodium orthovanadate, PMSF, sodium pyrophosphate, and $10 \mu \mathrm{g} / \mathrm{ml}$ each of aprotinin and leupeptin) and $10 \mathrm{mM}$ DTT (Argetsinger et al. 1993), and were rotated at room temperature for $15 \mathrm{~min}$ with vortexing. Eluates were diluted (1:10) with ChIP dilution buffer (16.7 mM Tris-HCl, $\mathrm{pH} 8 \cdot 0,167 \mathrm{mM} \mathrm{NaCl}, 1 \cdot 2 \mathrm{mM}$ EDTA, $0 \cdot 01 \%$ SDS, and $1 \cdot 1 \%$ Triton X-100) containing protease inhibitors as described above. Each eluted sample was divided into two for the second immunoprecipitation (re-ChIP) with $4 \mu \mathrm{g}$ of either anti-PCREB (rabbit), anti-CREB, anti-P-C/EBP $\beta$, anti-C/EBP $\beta$, no antibody (control), or normal rabbit $\mathrm{IgG}$ as control.

\section{Results}

Phosphorylated CREB participates in GH-stimulated c-fos expression

To evaluate whether CREB plays a role in GH-stimulated c-fos promoter activation, the response of c-fos to $\mathrm{GH}$ was analyzed in the presence of A-CREB, a dominant-negative form of CREB. Although A-CREB can dimerize with CREB, an acidic amphipathic extension in its basic region prevents the binding of the dimer to CRE sequences, including the c-fos CRE (Fig. 1A; Ahn et al. 1998). Activation of the c-fos promoter in response to $\mathrm{GH}$ in CHO-GHR cells is completely blocked when A-CREB is expressed (Fig. 1B). These results suggest that CREB is one of the transcription factors that participate in GH-stimulated c-fos expression.

$\mathrm{P}-\mathrm{CREB}$ is generally regarded as the transcriptionally active form of CREB. To understand whether phosphorylation of CREB at Ser 133 contributes to the activation of c-fos by $\mathrm{GH}$, the expression of endogenous c-fos mRNA was examined in the presence of WT CREB or a nonphosphorylatable mutant, S133A-CREB. GH induces its typical increase in c-fos mRNA levels in the presence of WT CREB in CHO-GHR cells (Fig. 1C, upper panel). However, the $\mathrm{GH}$-induced increment in c-fos mRNA is significantly reduced in the presence of $S 133 \mathrm{~A}-\mathrm{CREB}$, suggesting that the phosphorylation of CREB at Ser 133 contributes to GH-stimulated c-fos mRNA expression. Basal c-fos mRNA was not statistically different in cells expressing WT or mutant S133A-CREB, and the protein expression levels of CREB and S133A-CREB were comparable (Fig. 1C, lower panel). These findings support a role for phosphorylation of CREB at Ser 133 as an activating event for GH-stimulated c-fos transcription.

CREB phosphorylation at S133 can be induced by numerous stimuli (Shaywitz \& Greenberg 1999, Mayr \& Montminy 2001, Quinn 2002, Servillo et al. 2002). GH increases phosphorylation of endogenous CREB at Ser 133 at 10 and $30 \mathrm{~min}$, detected in 3T3-F442A preadipocytes by immunoblotting with an antibody that recognizes CREB phosphorylated at S133 (anti-P-CREB; Fig. 1D, top panel, lanes 2 and 3 vs 1 ). The response to $\mathrm{GH}$ is transient, since $\mathrm{P}-\mathrm{CREB}$ is substantially reduced at $60 \mathrm{~min}$ and returns to the basal level by $120 \mathrm{~min}$. Total CREB is detected at all times (Fig. 1D, middle panel) and appears to increase transiently $30 \mathrm{~min}$ after $\mathrm{GH}$ treatment. The relatively constant level of p65 (bottom panel) indicates equal loading. Similarly, GH induces P-CREB at 10 and $30 \mathrm{~min}$ in CHO-GHR cells (Fig. 1E, top panel). These findings extend the results of previous report that $\mathrm{P}-\mathrm{CREB}$ is detected $10 \mathrm{~min}$ after $\mathrm{GH}$ treatment of 3T3-F442A preadipocytes (Yarwood et al. 1998), indicating that stimulation of P-CREB by $\mathrm{GH}$ also occurs in other GH-responsive cells. Immunofluorescent staining of 3T3F442A cells using anti-P-CREB similarly revealed that GH induces a rapid and transient appearance of nuclear $\mathrm{P}-\mathrm{CREB}$ at $10 \mathrm{~min}$ which is reduced at $60 \mathrm{~min}$ (data not shown). Taken together, these observations suggest that the stimulation of $\mathrm{c}-f \circ$ by $\mathrm{GH}$ can be mediated by its induction of CREB phosphorylation. 
ERK1 and 2 mediate GH-stimulated activation of $c$-fos and phosphorylation of $C R E B$ and $C / E B P \beta$

Forskolin-stimulated c-fos promoter activation reflects stimulation of PKA which mediates phosphorylation of CREB at S133 and binding of P-CREB to the CRE 989. To evaluate whether PKA mediates activation of c-fos expression by GH, c-fos mRNA levels in response to GH were examined in the presence of H89, an inhibitor of PKA. The PKA inhibitor H89 failed to impair GH-induced expression of endogenous c-fos in 3T3-F442A preadipocytes (Fig. 2A), although H89 effectively inhibited forskolin-induced c-fos expression (Fig. 2B). Thus, it is unlikely that PKA mediates the stimulation of $c-f o s$ by GH. Interestingly, when the MEK inhibitor UO126, which blocks MAPK pathway signaling, was tested in conjunction with GH, UO126 blocked GH-induced c-fos mRNA (Fig. 2A) and protein expression (Fig. 2C). The UO126 impaired the GH-stimulated phosphorylation of endogenous CREB (Fig. 2D); it also inhibited the phosphorylation of endogenous C/EBP $\beta$ (Fig. 2E), another GH-regulated transcription factor mediating c-fos activation. The inhibition of phosphorylation of these proteins was accompanied by inhibition of GH-induced phosphorylation of ERK1/2 in 3T3-F442A nuclear extracts (Fig. 2F). These findings suggest that the phosphorylation of CREB at $\mathrm{S} 133$ in response to $\mathrm{GH}$, similar to phosphorylation of C/EBP $\beta$ at T188 (Piwien-Pilipuk et al. 2002), is mediated by activation of ERK $1 / 2$, and may contribute to GH-stimulated expression of endogenous c-fos.

\section{GH induces the rapid occupancy of endogenous P-CREB} and $P-C / E B P \beta$ on the $c$-fos promoter

For insight into the mechanism by which P-CREB mediates GH-stimulated c-fos transcription in intact cells, the occupancy of endogenous $\mathrm{P}-\mathrm{CREB}$ on the c-fos promoter was examined by ChIP. GH significantly increases the occupancy of endogenous P-CREB on c-fos in vivo at $15 \mathrm{~min}$ (Fig. 3A). As reported previously (Cui et al. 2005), GH also increases the occupancy of $\mathrm{P}-\mathrm{C} / \mathrm{EBP} \beta$ on $\mathrm{c}-f_{0 s}$ at $15 \mathrm{~min}$ (Fig. 3A) in parallel with P-CREB. The occupancy of total CREB or C/EBP $\beta$ also increased after $\mathrm{GH}$ treatment, although such increases were somewhat inconsistent, reflecting variations in the constitutive occupancy of these transcription factors on the c-fos promoter in the absence of GH. Simultaneously, GH increased the occupancy of phosphorylated RNA polymerase II on c-fos (Fig. 3A). These changes coincide with the stimulation of $\mathrm{c}-$ fos expression induced by GH at 15-30 min (Doglio et al. 1989, Gurland et al. 1990). As controls, c-fos promoter DNA was not detected in the absence of antibodies (Fig. 3A), or by control primers amplifying a $5^{\prime}$ distal region of c-fos (Supplementary Fig. S1). These findings indicate that GH induces the phosphorylation and/or the occupancy of $\mathrm{P}-\mathrm{CREB}$ and $\mathrm{P}-\mathrm{C} / \mathrm{EBP} \beta$ on the $\mathrm{c}-$ fos promoter, opening the possibility that these phosphorylated transcription factors might work cooperatively in a complex with other proteins to increase c-fos transcription.
To ascertain whether ERK-mediated phosphorylation of CREB or C/EBP $\beta$ contributes to their occupancy on c-fos, ChIP was performed on cells treated with the MEK inhibitor UO126, or the vehicle DMSO, for 30 min prior to GH. For P-CREB, the GH-induced increase in its occupancy (Fig. 3B, lane 2 vs 1) was almost completely blocked by UO126 (lane 4 vs 3). In multiple experiments, the reduction by $\mathrm{UO} 126$ in GH-induced occupancy $(\mathrm{GH} / \mathrm{C})$ for P-CREB $(86 \%$ decrease) suggests a role for ERKs in the response of $\mathrm{P}-\mathrm{CREB}$ to GH. The occupancy of P-C/EBP $\beta$ in GH-treated cells was slightly less $(15 \%$ decrease) in the presence of UO126 than DMSO in multiple experiments. Interestingly, the GH-induced occupancy of P-Pol II was also reduced by UO126, resulting in $37 \%$ reduction relative to DMSO in multiple experiments. The reduced occupancy of these factors is consistent with the observed inhibition of GH-stimulated c-fos mRNA in the presence of UO126 (Fig. 2A). Together, these findings suggest that the $\mathrm{GH}$-induced phosphorylation of CREB and the occupancy of P-CREB on c-fos are dependent on ERK1/2. Since ERKs also mediate the phosphorylation of C/EBP $\beta$ in response to $\mathrm{GH}$, and $\mathrm{P}-\mathrm{C} / \mathrm{EBP} \beta$ as well as $\mathrm{P}-\mathrm{CREB}$ occupies $c-f o s$, these findings suggest that $\mathrm{CREB}$ and $\mathrm{C} / \mathrm{EBP} \beta$ might be coordinately regulated on the $\mathrm{c}-$ fos promoter in response to $\mathrm{GH}$.

$c$-fos CRE mediates cooperation between CREB and C/EBP $\beta$, and $\mathrm{GH}$-stimulated transcription

Since GH-stimulated expression of endogenous c-fos is blocked in C/EBP $\beta$-deficient cells (Cui et al. 2005), CREB and $\mathrm{C} / \mathrm{EBP} \beta$ were tested in combination. The co-expression of CREB and C/EBP $\beta$ significantly enhances $c-f o s$ promoter activation compared with the activation by each factor individually (Fig. 4A, WT, black bar). A mutation in the CRE in the otherwise intact $\mathrm{c}-$ fos promoter (mCRE; Fig. 1A), which interferes with its ability to bind CREB (Berkowitz et al. 1989, Cui \& Schwartz, data not shown), impairs the enhancement of $c-f o s$ activation by the combination of CREB and C/EBP $\beta$ (Fig. 4A, mCRE, black bar). These observations suggest that CREB and C/EBP $\beta$ can enhance c-fos promoter activation cooperatively, and that their cooperation requires an intact CRE. These findings complement a previous report of cooperation of CREB and C/EBP $\beta$ mediated by a consensus CRE (Chen et al. 2003). Activation of the c-fos promoter by GH was also significantly impaired by mutation of the CRE (Fig. 4B). These findings indicate that the CRE can mediate $\mathrm{GH}$-stimulated c-fos transcription, and is a site for cooperative regulation by CREB and C/EBP $\beta$.

\section{GH promotes the occupancy of both CREB and $C / E B P \beta$ on the same $c$-fos promoter DNA}

Since GH simultaneously increases the occupancy of both $\mathrm{P}-\mathrm{CREB}$ and $\mathrm{P}-\mathrm{C} / \mathrm{EBP} \beta$ on $\mathrm{c}-$ fos, it was of interest to test whether these two transcription factors might be present together in a regulatory complex occupying $c-f o s$ in response 
A

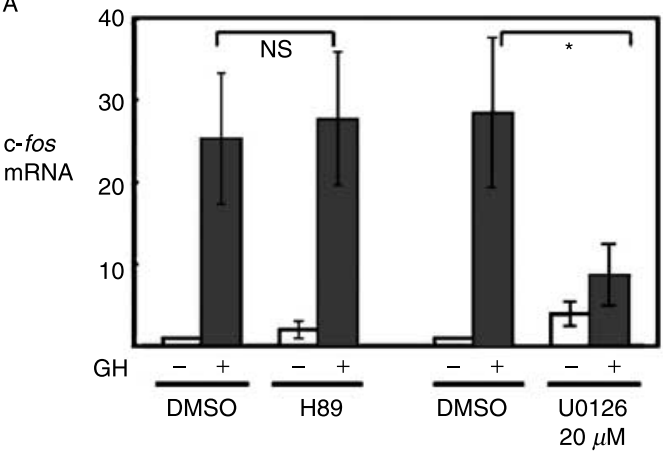

B

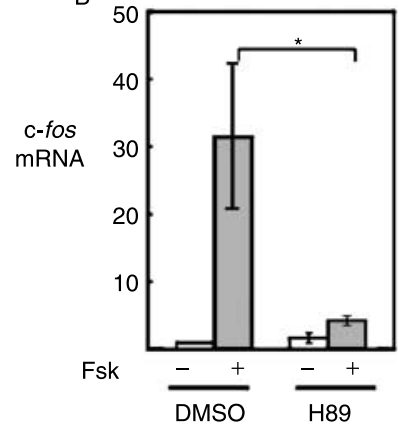

C
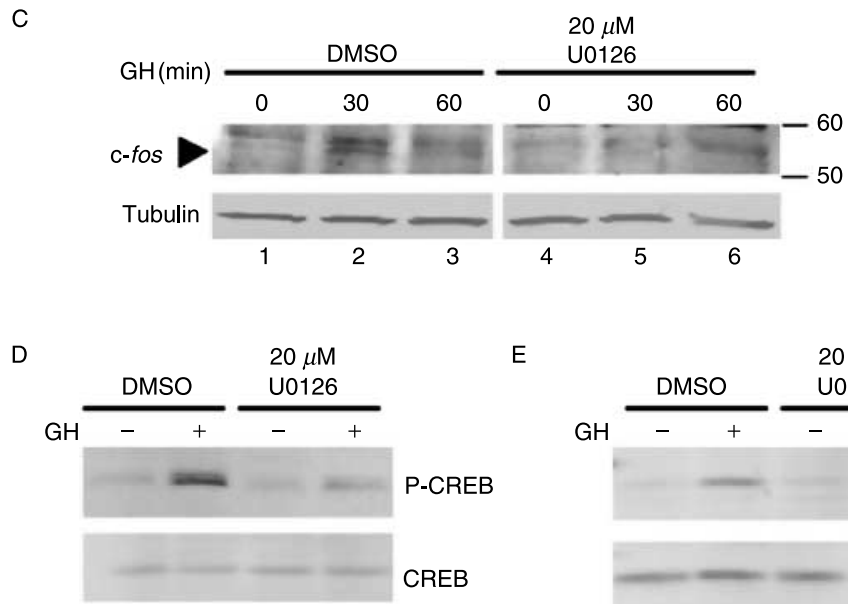

$\mathrm{E}$
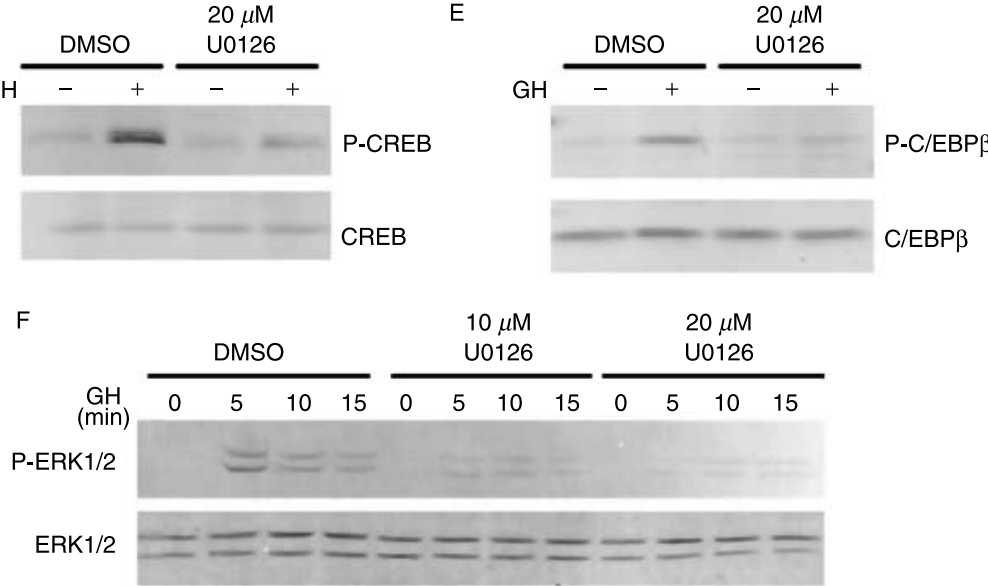

Figure 2 ERK1 and 2 mediate GH-stimulated phosphorylation of CREB and activation of c-fos. (A) 3T3F442A preadipocytes were treated with $\mathrm{H} 89(20 \mu \mathrm{M})$ or an equivalent volume of DMSO vehicle for $4 \mathrm{~h}$ (left), or with UO126 $(20 \mu \mathrm{M})$ or equivalent DMSO for $30 \mathrm{~min}$ (right). Cells were then treated without (open bars) or with GH (black bars) for an additional 30 min. c-fos mRNA was analyzed by QT-PCR and is presented as mean \pm s.E.M. $(n=3)$. H89 failed to alter $\mathrm{GH}$-induced c-fos expression. UO126 significantly $(P<0 \cdot 05)$ reduced $\mathrm{GH}$-induced c-fos mRNA expression. (B) H89 blocks forskolin-stimulated c-fos mRNA expression. To verify the effectiveness of H89, 3T3-F442A cells were treated with $\mathrm{H} 89(20 \mu \mathrm{M})$ or DMSO for $4 \mathrm{~h}$, followed by forskolin $(30 \mu \mathrm{M})$ for $30 \mathrm{~min}$. Total RNA was prepared and analyzed for c-fos mRNA by QT-PCR. H89 significantly inhibited forskolin-induced c-fos expression $(P<0 \cdot 001$, gray bars). The results are shown as mean \pm s.E.M. $(n=3)$. (C) 3T3-F442A cells were treated with UO126 $(20 \mu \mathrm{M})$ or DMSO for $30 \mathrm{~min}$, followed by $\mathrm{GH}$ for the times indicated. Nuclear protein was analyzed by immunoblotting with anti-Fos. Similar results were obtained in two experiments. (D) 3T3-F442A cells were treated with UO126 $(20 \mu \mathrm{M})$ or DMSO for $30 \mathrm{~min}$, followed by GH treatment for $10 \mathrm{~min}$. Nuclear extracts were used for immunoblotting with anti-P-CREB or anti-CREB. Similar results were obtained in three experiments. (E) 3T3-F442A cells were treated with UO126 for $30 \mathrm{~min}$ and then treated with $\mathrm{GH}$ for $10 \mathrm{~min}$. Nuclear protein was analyzed by immunoblotting using anti-P-C/EBP $\beta$ or anti-C/EBP $\beta$. Similar results were obtained in three experiments. (F) 3T3-F442A cells were treated with UO126 (10 or $20 \mu \mathrm{M})$ or equivalent volumes of DMSO for $30 \mathrm{~min}$ followed by $\mathrm{GH}$ for the times indicated. Nuclear protein was analyzed by immunoblotting with anti-PERK1/2 or anti-ERK1/2. Increasing amounts of the inhibitor UO126 reduced GH-stimulated ERK activation (P-ERK1/2), while total ERK1/2 was not changed. Similar results were obtained in three experiments. 
A

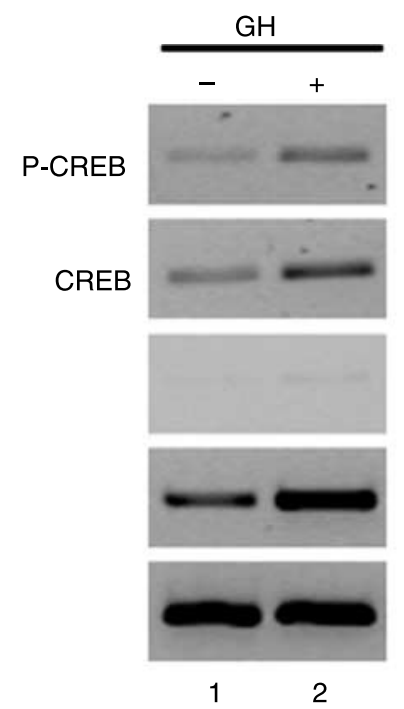

B
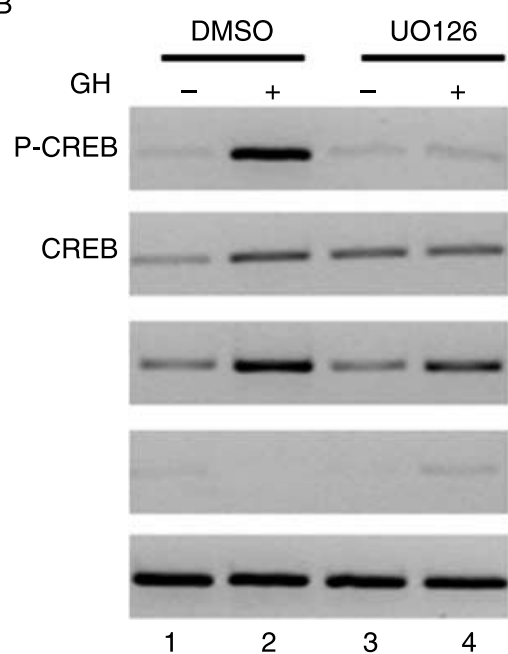
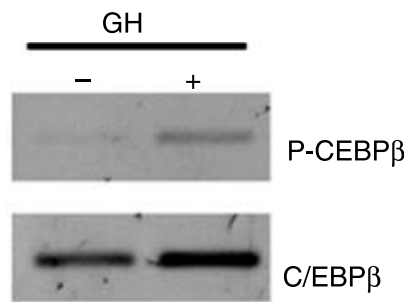

Control

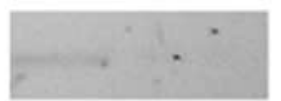

P-Pol II

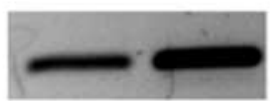

Input

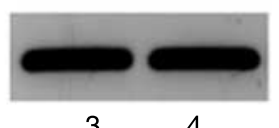

3

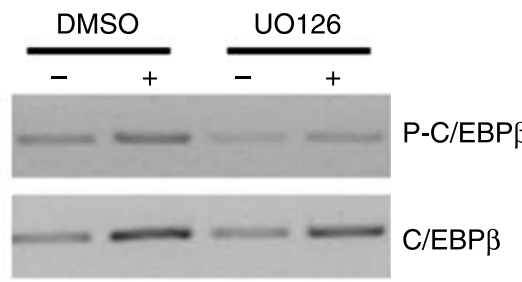

P-Pol II

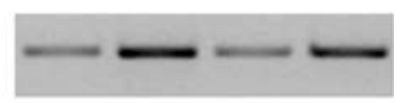

Control

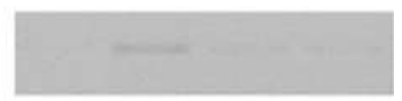

Input

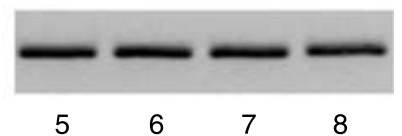

Figure $3 \mathrm{GH}$ induces the occupancy of P-CREB and P-C/EBP $\beta$ on c-fos. (A) 3T3-F442A cells were treated with GH for $15 \mathrm{~min}$. Nuclear extracts were prepared for ChIP with anti-P-CREB and anti-CREB, or for ChIP with anti-P-C/EBP $\beta$ and anti-C/EBP $\beta$, along with anti-P-Pol II or without antibody (control). One percentage of input is shown in this and subsequent figures. C-fos promoter DNA was amplified with ChIP PCR primers $\mathrm{P} 1$ and $\mathrm{P} 2$. Quantified results from multiple independent experiments indicate significant $(P<0 \cdot 05)$ stimulation by $\mathrm{GH}$ of occupancy where $\mathrm{GH} / \mathrm{C}$ (mean \pm s.E.M.) for P-CREB was $2 \cdot 2 \pm 0 \cdot 6(n=5)$, for P-C/EBP $\beta$ was $6 \cdot 4 \pm 0 \cdot 3(n=3)$, and for P-Pol II was $2 \cdot 2 \pm 0 \cdot 3(n=5) . \mathrm{GH} / \mathrm{C}$ for CREB was $1 \cdot 5 \pm 0 \cdot 5$ $(n=3)$ and for C/EBP $\beta$ was $1 \cdot 6 \pm 0 \cdot 4(n=3)$. (B) $3 T 3-F 442 A$ cells were treated with UO126 $(20 \mu \mathrm{M})$ or DMSO for $30 \mathrm{~min}$ and then with GH for an additional $15 \mathrm{~min}$. Nuclear extracts were analyzed by ChIPas described. Quantified results from multiple independent experiments indicate stimulation by $\mathrm{GH}$ of occupancy $(\mathrm{GH} / \mathrm{C}$, mean \pm S.E.M.) for P-CREB was $9 \cdot 0 \pm 4 \cdot 4$ (DMSO) and $1 \cdot 2 \pm 0 \cdot 4$ (UO126; $n=4)$; for P-C/EBP $\beta$ was $1 \cdot 4 \pm 0 \cdot 1(\mathrm{DMSO})$ and $1 \cdot 2 \pm 0 \cdot 4(\mathrm{UO} 126 ; n=3)$; and for P-Pol II was $3 \cdot 5 \pm 0 \cdot 3$ (DMSO) and $2 \cdot 2 \pm 0 \cdot 3(\mathrm{UO} 126 ; n=5) . \mathrm{GH} / \mathrm{C}$ for CREB was $1 \cdot 5 \pm 0 \cdot 6(\mathrm{DMSO})$ and $1 \cdot 0 \pm 0 \cdot 04(\mathrm{UO} 126 ; n=4)$ and for $\mathrm{C} / \mathrm{EBP} \beta$ was $2 \cdot 8 \pm 1 \cdot 1(\mathrm{DMSO})$ and $1 \cdot 4 \pm 0 \cdot 3(\mathrm{UO} 126 ; n=4)$.

to $\mathrm{GH}$. To evaluate whether CREB and C/EBP $\beta$ occupy the same c-fos promoter DNA, samples from GH-treated 3T3F442A preadipocytes were subjected to sequential ChIP and re-ChIP. After the first ChIP with anti-C/EBP $\beta$, in which the occupancy of $\mathrm{C} / \mathrm{EBP} \beta$ on $c$-fos was increased by GH at
15 min (Fig. 5, first IP), the c-fos-C/EBP $\beta$ complex was eluted from the beads, and eluates were subjected to a second immunoprecipitation using antibodies against P-CREB. Endogenous P-CREB clearly occupied the same c-fos DNA as $\mathrm{C} / \mathrm{EBP} \beta$, and was markedly increased in response to $\mathrm{GH}$ 


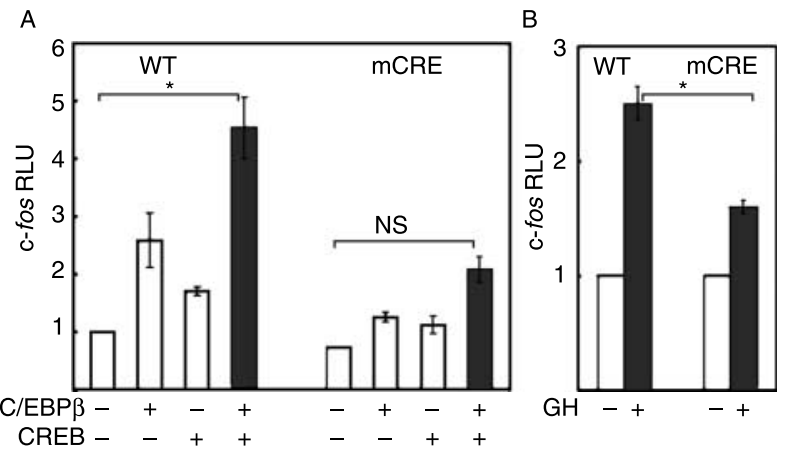

CREB - - + + $-c_{+}+$

Figure $4 \mathrm{CREB}$ and $\mathrm{C} / \mathrm{EBP} \beta$ cooperatively increase $\mathrm{C}-$ fos promoter activation. (A) Plasmids for CREB (100 ng) or C/EBP $\beta$ (25 ng) were expressed alone or in combination with WT or mutant mCRE fos-Luc $(0.5 \mu \mathrm{g}$ each) and $\beta$-gal $(0 \cdot 1 \mu \mathrm{g})$ in $\mathrm{CHO}-\mathrm{GHR}$ cells. Luciferase activity was measured ( $n=3$ independent experiments). Expression of CREB and $\mathrm{C} / \mathrm{EBP} \beta$ in combination $(\mathrm{WT}$, black bar) significantly $(P<0 \cdot 05)$ enhances WT c-fos promoter activation compared with the activation produced by expression of CREB or C/EBP $\beta$ individually (open bars). The enhancement was blocked when the CRE in the c-fos promoter was mutated (mCRE versus WT, black bars). (B) Plasmids for WT or mCRE fos-Luc ( $0.5 \mu \mathrm{g}$ each) were expressed with $\beta$-gal $(0.1 \mu \mathrm{g})$ in $\mathrm{CHO}-\mathrm{GHR}$ cells. Cells were treated without (open bars) or with (black bars) $\mathrm{GH}$ as described ( $n=3$ independent experiments). The increase in c-fos promoter activation due to $\mathrm{GH}$ is significantly $(P<0 \cdot 05)$ reduced with $\mathrm{mCRE}$ versus WT.

(Fig. 5, second IP, top panels). Controls which did not include antibodies did not precipitate c-fos promoter DNA. The converse experiment, in which the first IP with anti-CREB was examined for $\mathrm{P}-\mathrm{C} / \mathrm{EBP} \beta$ in a second IP revealed that $\mathrm{GH}$ also induced the occupancy of $\mathrm{P}-\mathrm{C} / \mathrm{EBP} \beta$ on the same $\mathrm{c}-f \circ s$ DNA occupied by CREB (Fig. 5, second IP, lower panels). These observations support the presence of both P-CREB

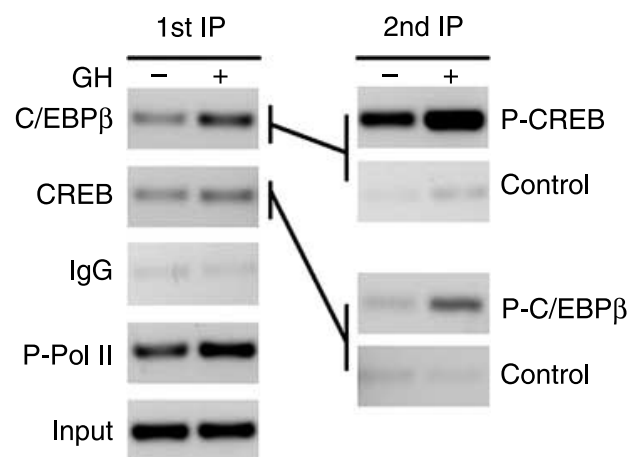

Figure $5 \mathrm{GH}$ promotes occupancy of both CREB and C/EBP $\beta$ on the same c-fos promoter DNA. 3T3-F442A cells were treated with GH for 15 min. Nuclear extracts were subjected to ChIP (first IP) using antiC/EBP $\beta$, anti-CREB, anti-P-Pol II, or normal rabbit IgG as control. After the first ChIP with anti-C/EBP $\beta$, beads were eluted as described in Materials and Methods, and eluates were immunoprecipitated using anti-P-CREB (rabbit) or no antibody as described (second IP, top panels). Conversely, after the first ChIP with anti-CREB, eluates were immunoprecipitated using anti-P-C/EBP $\beta$ (second IP, bottom panels). Similar results were obtained in three experiments. and $\mathrm{P}-\mathrm{C} / \mathrm{EBP} \beta$ on the same $\mathrm{c}-$ fos $\mathrm{DNA}$ in $\mathrm{GH}$-treated cells. Complementary to these observations, $\mathrm{GH}$-induced cooccupancy of total CREB and C/EBP $\beta$ on $c-f o s$ is also observed by re-ChIP with antibodies against C/EBP $\beta$ or CREB in the second IPs (Cui \& Schwartz, data not shown).

These observations that endogenous P-CREB and $\mathrm{P}-\mathrm{C} / \mathrm{EBP} \beta$ co-occupy the same c-fos promoter DNA in response to $\mathrm{GH}$ are consistent with the observed cooperation of CREB and C/EBP $\beta$ in activating $c-f o s$, and with the increased occupancy of both P-CREB and P-C/EBP $\beta$ in response to $\mathrm{GH}$. Taken together, these findings are consistent with GH coordinately stimulating the phosphorylation of CREB and C/EBP $\beta$, possibly by activation of ERK1/2, facilitating their combined occupancy, and cooperative activation of the c-fos promoter.

\section{Discussion}

GH increases CREB phosphorylation and occupancy on the $c$-fos promoter in vivo

This study adds to our understanding of the mechanisms by which $\mathrm{GH}$ regulates gene transcription and by demonstrating a role for the c-fos CRE and CREB in GH-stimulated c-fos expression. Not only does expression of the dominant-negative CREB, A-CREB, prevent GH-induced c-fos promoter activation, but also mutation of the c-fos CRE impairs it. GH activates CREB by the well-established mechanism of stimulating CREB phosphorylation at Ser 133. Mutation of CREB at Ser 133 impaired GH-stimulated c-fos mRNA expression. Further, GH increases the occupancy of endogenous $\mathrm{P}-\mathrm{CREB}$ on $\mathrm{c}-$ fos promoter DNA. The timing of the increased occupancy of P-CREB coincides with the rapid increase in CREB phosphorylation induced by $\mathrm{GH}$, as well as with increased occupancy of P-Pol II and GH-stimulated c-fos mRNA expression. It remains to be determined whether $\mathrm{GH}$ stimulates the phosphorylation of unbound CREB that is newly recruited to the promoter, or whether it increases the phosphorylation of CREB already occupying c-fos. These findings open new possibilities for understanding cooperation among multiple GH-regulated transcription mechanisms.

Cooperativity between CREB and C/EBP $\beta$, a transcription factor critical for GH-stimulated c-fos expression (Cui et al. 2005), is supported by demonstrating that GH stimulates the occupancy of P-CREB on the same c-fos DNA as $\mathrm{C} / \mathrm{EBP} \beta$, and of $\mathrm{P}-\mathrm{C} / \mathrm{EBP} \beta$ on the same DNA as CREB. The combination of CREB and C/EBP $\beta$ enhances $c-$ fos promoter activation via the CRE relative to either transcription factor alone. Cooperation between C/EBP $\beta$ and CREB in activating CRE-Luc has also been reported in osteoblasts (Chen et al. 2003), indicating that such cooperation occurs in different cell types. Taken together, these findings support a model in which GH activates CREB and $\mathrm{C} / \mathrm{EBP} \beta$ cooperatively to increase $\mathrm{c}-$ fos transcription. 
ERKs mediate GH-induced phosphorylation of CREB to regulate $c$-fos expression

$\mathrm{GH}$ promotes the phosphorylation of CREB by a mechanism involving activation of ERK1/2. Both the stimulation by $\mathrm{GH}$ of the phosphorylation of CREB and the occupancy of P-CREB on c-fos, as well as c-fos mRNA and protein expression, were reversed by inhibition of MEK with U0126. GH-stimulated ERK1/2 and their downstream kinase $\mathrm{pp} 90^{\mathrm{Rsk}}$ are likely mediators of the phosphorylation of CREB. In contrast, inhibition of PKA by H89, an established activator of CREB phosphorylation failed to alter GH-stimulated c-fos expression. The mediation of GH-regulated CREB phosphorylation by MAPK rather than by PKA agrees with previous observations that the ability of $\mathrm{GH}$ to regulate cAMP/PKA signaling is modest (Gorin et al. 1976, Birnbaum \& Goodman 1979, Yarwood et al. 1998). In contrast, the ability of GH to activate MAPK signaling pathways is well established (Moller et al. 1992, Winston \& Bertics 1992, VanderKuur et al. 1995). It should be noted that an inhibitor of the MAPK p38 (SB205380) failed to impair GH-induced c-fos expression in the present studies (Cui \& Schwartz, data not shown), suggesting that c-fos activation by $\mathrm{GH}$ is specific for ERK1/2. Since transcription factors other than CREB are phosphorylated in response to $\mathrm{GH}$ via activation of ERK1/2, the inhibition of GH-stimulated c-fos mRNA expression by U1026 may also reflect impaired phosphorylation of $\mathrm{C} / \mathrm{EBP} \beta$, Elk-1, or other factors (Hodge et al. 1998, Zhu \& Lobie 2000, Piwien-Pilipuk et al. 2002). In fact, it is likely that CREB acts in concert with other GH-regulated transcription factors, since mutation of the CRE only partially blocks GH-stimulated c-fos promoter activation. The residual response to GH may reflect the contribution of the other GH-regulated factors, and their potential interactions with CREB. Whether the phosphorylation of Pol II on Ser 5, which can also be mediated by ERKs (Trigon et al. 1998, Oelgeschlager 2002), reflects activation of ERKs by GH remains to be determined.

The relatively similar mechanisms for phosphorylation of CREB and C/EBP $\beta$ by $\mathrm{GH}$, as well as their cooperative occupancy on c-fos in response to $\mathrm{GH}$, suggest that the regulation of their phosphorylation might be a coordinating factor for their cooperative regulation of c-fos. In fact, ERKs might themselves be associated with a complex on c-fos. Accumulating evidence indicates that MAPKs can become associated with the gene promoters that they regulate in the yeast genome (Edmunds \& Mahadevan 2006, Pokholok et al. 2006). If ERK1/2, like p38 (Simone et al. 2004), are similarly present in complexes on a mammalian gene such as c-fos, activation by a signal such as $\mathrm{GH}$ could serve to phosphorylate transcription factors constitutively occupying the promoter DNA. Phosphorylation and activation of several factors such as CREB and C/EBP $\beta$ could thereby be coordinated, facilitating their recruitment of other nuclear factors such as CBP or p300 to activate transcription. GH may also regulate additional factors whose phosphorylation enables them to occupy $c-f o s$, or other genes, which coordinately regulate $\mathrm{GH}$-induced transcription.

\section{GH induces the combined occupancy of P-CREB and $P$-C/EBP $\beta$ on $c$-fos $D N A$}

CREB has been considered to serve as a platform for formation of nucleoprotein complexes on target genes. Such complexes contain co-activators such as CBP (Chrivia et al. 1993, Kwok et al. 1994), enzymes such as PP1 and HDACs (Canettieri et al. 2003), and other transcription factors (Chen et al. 2003). The present study confirms that CREB and C/EBP $\beta$ cooperatively enhance $\mathrm{c}$-fos promoter activation and demonstrates that $\mathrm{GH}$ induces the combined occupancy of activated CREB and $\mathrm{C} / \mathrm{EBP} \beta$ on the $\mathrm{c}-$ fos promoter. Endogenous P-CREB occupies the same c-fos DNA immunoprecipitated by anti$\mathrm{C} / \mathrm{EBP} \beta$, and GH increases the appearance of P-CREB on the same DNA occupied by $C / E B P \beta$. This novel finding suggests that $\mathrm{P}-\mathrm{CREB}$ and $\mathrm{P}-\mathrm{C} / \mathrm{EBP} \beta$ may be part of a regulated complex that occupies c-fos in response to GH. In previous studies, the combined occupancy of C/EBP $\beta$ and the co-activator $\mathrm{p} 300$ on $\mathrm{c}-f o s$ was induced by GH (Cui et al. 2005). Taken together, these findings raise the possibility that a regulatory complex occupying c-fos in response to $\mathrm{GH}$ contains $\mathrm{P}-\mathrm{CREB}$ and $\mathrm{P}-\mathrm{C} / \mathrm{EBP} \beta$, and a co-activator(s) such as $\mathrm{p} 300$ and/or the homologous factor CBP.

This study suggests that a complex on c-fos containing CREB and C/EBP $\beta$ might be tethered at the CRE. C/EBP $\beta$ might associate with CREB in a complex that occupies the $\mathrm{CRE}$, since C/EBP $\beta$ co-precipitates with CREB (Chen et al. 2003), and this study shows that mutation of the CRE prevented the enhancement of transcription with the simultaneous expression of CREB and C/EBP $\beta$. The CRE and the $\mathrm{C} / \mathrm{EBP}$ site in the murine and human $\mathrm{c}-$ fos promoters are separated by $\sim 200 \mathrm{bp}$. A highly positioned nucleosome has been identified on human c-fos between the C/EBP site and the CRE (Herrera et al. 1997). One can envision that the nucleosome brings the C/EBP site and the CRE, and the proteins associated with them, into proximity, facilitating interactions that allow formation of a complex containing $\mathrm{C} / \mathrm{EBP} \beta$ and CREB on c-fos. Alternatively, CREB and/or $\mathrm{C} / \mathrm{EBP} \beta$ might be present in multiple complexes that occupy different sites on c-fos. Analysis of CREB and $\mathrm{C} / \mathrm{EBP} \beta$ on other promoters such as phosphoenolpyruvate carboxykinase (PEPCK; Wilson et al. 2002), as well as genome-wide analysis of CREB target genes (Impey et al. 2004, Zhang et al. 2005) and expression profiling of C/EBP $\beta$ target genes (Friedman et al. 2004), support the importance of additional regulatory partners cooperating with CREB and $\mathrm{C} / \mathrm{EBP} \beta$ in transcriptional activation. A complex containing CREB and C/EBP $\beta$ is likely to recruit p300 and/or CBP. It will be of interest to identify other components of GH-induced complexes that contain CREB and C/EBP $\beta$. 


\section{Acknowledgements}

This work was supported by NIH Grant DK46072 and a grant from the Biomedical Research Council at the University of Michigan (to J S), and by NIH grant DK067102 (to R K). The authors thank C Fulton for technical assistance, Dr L Argetsinger and Dr T Cesena for critical reading of the manuscript. The authors declare that there is no conflict of interest that would prejudice the impartiality of this scientific work.

\section{References}

Ahn S, Olive M, Aggarwal S, Krylov D, Ginty DD \& Vinson C 1998 A dominant-negative inhibitor of CREB reveals that it is a general mediator of stimulus-dependent transcription of $c-$ fos. Molecular and Cellular Biology 18 67-977.

Argetsinger LS, Campbell GS, Yang X, Wittuhn BA, Silvennoinen O, Ihle JN \& Carter-Su C 1993 Identification of JAK2 as a growth hormone receptorassociated tyrosine kinase. Cell 74 237-244.

Ashcom G, Gurland G \& Schwartz J 1992 Growth hormone synergizes with serum growth factors in inducing c-fos transcription in 3T3-F442A cells. Endocrinology 131 1915-1921.

Berkowitz LA, Riabowol KT \& Gilman MZ 1989 Multiple sequence elements of a single functional class are required for cyclic AMP responsiveness of the mouse c-fos promoter. Molecular and Cellular Biology 9 4272-4281.

Birnbaum RS \& Goodman HM 1979 Comparison of several insulin-like effects of growth hormone. Hormone and Metabolic Research 11 136-142.

Boutillier AL, Barthel F, Roberts JL \& Loeffler JP 1992 B-adrenergic stimulation of $\mathrm{cFOS}$ via protein kinase $\mathrm{A}$ is mediated by cAMP regulatory element binding protein (CREB)-dependent and tissue-specific CREBindependent mechanisms in corticotrope cells. Journal of Biological Chemistry $26723520-23526$

Canettieri G, Morantte I, Guzman E, Asahara H, Herzig S, Anderson SD, Yates JR, III \& Montminy M 2003 Attenuation of a phosphorylationdependent activator by an HDAC-PP1 complex. Nature Structural Biology 10 175-181.

Cesena TI, Cui TX, Piwien-Pilipuk G, Kaplani JI, Calinescu AA, Huo JS, Iniguez-Lluhi JA, Kwok R \& Schwartz J 2007 Multiple mechanisms of growth hormone-regulated gene transcription. Molecular Genetics and Metabolism 90 126-133.

Cha-Molstad H, Keller DM, Yochum GS, Impey S \& Goodman RH 2004 Cell-type-specific binding of the transcription factor CREB to the cAMPresponse element. PNAS 101 13572-13577.

Chen CM, Clarkson RW, Xie Y, Hume DA \& Waters MJ 1995 Growth hormone and colony-stimulating factor 1 share multiple response elements in the $c$-fos promoter. Endocrinology 136 4505-4516.

Chen Y, Zhuang S, Cassenaer S, Casteel DE, Gudi T, Boss GR \& Pilz RB 2003 Synergism between calcium and cyclic GMP in cyclic AMP response element-dependent transcriptional regulation requires cooperation between CREB and C/EBP $\beta$. Molecular and Cellular Biology 23 4066-4082.

Chrivia JC, Kwok RP, Lamb N, Hagiwara M, Montminy MR \& Goodman RH 1993 Phosphorylated CREB, binds specifically to the nuclear protein CBP. Nature 365 855-859.

Clarkson RWE, Chen CM, Harrison S, Wells C, Muscat GEO \& Waters MJ 1995 Early responses of trans-activating factors to growth hormone in preadipocytes: differential regulation of CCAAT enhancer-binding protein- $\beta(\mathrm{C} / \mathrm{EBP} \beta)$ and C/EBP $\delta$. Molecular Endocrinology 9 108-120.

Cosma MP 2002 Ordered recruitment: gene-specific mechanism of transcription activation. Molecular Cell 10 227-236.
Cui TX, Piwien-Pilipuk G, Huo JS, Kaplani J, Kwok R \& Schwartz J 2005 Endogenous CCAAT/enhancer binding protein $\beta$ and p300 are both regulated by growth hormone to mediate transcriptional activation. Molecular Endocrinology 19 2175-2186.

Doglio A, Dani C, Grimaldi P \& Ailhaud G 1989 Growth hormone stimulates c-fos gene expression by means of protein kinase $\mathrm{C}$ without increasing inositol lipid turnover. PNAS 86 1148-1152.

Edmunds JW \& Mahadevan LC 2006 Cell signaling. Protein kinases seek close encounters with active genes. Science 313 449-451.

Fass DM, Butler JE \& Goodman RH 2003 Deacetylase activity is required for cAMP activation of a subset of CREB target genes. Journal of Biological Chemistry 278 43014-43019.

Fisch TM, Prywes R, Simon MC \& Roeder RG 1989 Multiple sequence elements in the c-fos promoter mediate induction by cAMP. Genes and Development 3 198-211.

Friedman JR, Larris B, Le PP, Peiris TH, Arsenlis A, Schug J, Tobias JW, Kaestner KH \& Greenbaum LE 2004 Orthogonal analysis of C/EBP $\beta$ targets in vivo during liver proliferation. PNAS 101 12986-12991.

Gong T-WL, Meyer DJ, Liao J, Hodge CL, Campbell GS, Wang X, Billestrup N, Carter-Su C \& Schwartz J 1998 Regulation of glucose transport and c-fos and egr-1 expression in cells with mutated or endogenous growth hormone receptors. Endocrinology 139 1863-1871.

Gonzalez GA \& Montminy MR 1989 Cyclic AMP stimulates somatostatin gene transcription by phosphorylation of CREB at serine 133. Cell $\mathbf{5 9}$ 675-680.

Gorin E, Honeyman TW \& Goodman HM 1976 Independent modulation of hepatic protein kinase activities. Biochimica et Biophysica Acta 451 491-498.

Gronowski AM \& Rotwein P 1994 Rapid changes in nuclear protein tyrosine phosphorylation after growth hormone treatment in vivo. Identification of phosphorylated mitogen-activated protein kinase and stat91. Journal of Biological Chemistry 269 7874-7878.

Gronowski AM, Zhong Z, Wen W, Thomas MJ, Darnell JE, Jr \& Rotwein P 1995 In vivo growth hormone treatment rapidly stimulates the tyrosine phosphorylation and activation of Stat3. Molecular Endocrinology 9 171-177.

Gronowski AM, Stunff CL \& Rotwein P 1996 Acute nuclear actions of growth hormone $(\mathrm{GH})$ : cycloheximide inhibits inducible activator protein-1 activity, but does not block GH-regulated signal transducer and activator of transcription activation or gene expression. Endocrinology 137 55-64.

Gurland G, Ashcom G, Cochran BH \& Schwartz J 1990 Rapid events in growth hormone action. Induction of c-fos and c-jun transcription in 3T3-F442A preadipocytes. Endocrinology 127 3187-3195.

Hanlon M, Bundy LM \& Sealy L 2000 C/EBP beta and Elk-1 synergistically transactivate the c-fos serum response element. BMC Cell Biology 12.

Hanlon M, Sturgill TW \& Sealy L 2001 ERK2- and p $90^{\text {Rsk2 }}$-dependent pathways regulate the CCAAT/enhancer-binding protein- $\beta$ interaction with serum response factor. Journal of Biological Chemistry 276 38449-38456.

Herrera RE, Nordheim A \& Stewart AF 1997 Chromatin structure analysis of the human c-fos promoter reveals a centrally positioned nucleosome. Chromosoma 106 284-292.

Hodge C, Liao J, Stofega M, Guan K, Carter-Su C \& Schwartz J 1998 Growth hormone stimulates phosphorylation and activation of Elk-1 and expression of $c$-fos, egr-1, and $7 j u n B$ through activation of extracellular signal-regulated kinases 1 and 2. Journal of Biological Chemistry 273 31327-31336.

Holt JT, Gopal TV, Moulton AD \& Nienhuis AW 1986 Inducible production of c-fos antisense RNA inhibits 3T3 cell proliferation. PNAS $\mathbf{8 3}$ 4794-4798.

Huo JS, McEachin RC, Cui TX, Duggal NK, Hai T, States DJ \& Schwartz J 2006 Profiles of growth hormone (GH)-regulated genes reveal timedependent responses and identify a mechanism for regulation of activating transcription factor 3 by GH. Journal of Biological Chemistry 281 4132-4141.

Impey S, McCorkle SR, Cha-Molstad H, Dwyer JM, Yochum GS, Boss JM, McWeeney S, Dunn JJ, Mandel G \& Goodman RH 2004 Defining the CREB regulon: a genome-wide analysis of transcription factor regulatory regions. Cell 119 1041-1054.

Kwok RP, Lundblad JR, Chrivia JC, Richards JP, Bachinger HP, Brennan RG, Roberts SG, Green MR \& Goodman RH 1994 Nuclear protein CBP is a coactivator for the transcription factor CREB. Nature 370 223-226. 
Liao J, Hodge CL, Meyer DJ, Ho PS, Rosenspire KC \& Schwartz J 1997 Growth hormone regulates ternary complex factors and serum response factor associated with the c-fos serum response element. Journal of Biological Chemistry 272 25951-25958.

Liao J, Piwien-Pilipuk G, Ross SE, Hodge CL, Sealy L, MacDougald OA \& Schwartz J 1999 CCAAT/Enhancer-binding protein beta (C/EBP beta) and $\mathrm{C} / \mathrm{EBP} \delta$ contribute to growth homone-regulated transcription of c-fos. Journal of Biological Chemistry 274 31597-31604.

Mayr B \& Montminy M 2001 Transcriptional regulation by the phosphorylation-dependent factor CREB. Nature Reviews. Molecular Cell Biology 2 599-609.

Merika M \& Thanos D 2001 Enhanceosomes. Current Opinion in Genetics and Development 11 205-208.

Meyer DJ, Stephenson EW, Johnson L, Cochran BH \& Schwartz J 1993 The serum response element can mediate induction of $\mathrm{c}-$ fos by growth hormone. PNAS 90 6721-6725.

MeyerDJ, Campbell GS, Cochran BH, Argetsinger LS, Larner AC, Finbloom DS, Carter-Su C \& Schwartz J 1994 Growth hormone induces a DNA binding factor related to the interferon-stimulated $91-\mathrm{kDa}$ transcription factor. Journal of Biological Chemistry 269 4701-4704.

Moller C, Hansson A, Enberg B, Lobie PE \& Norstedt G 1992 Growth hormone $(\mathrm{GH})$ induction of tyrosine phosphorylation and activation of mitogen-activated protein kinase in cells transfected with rat GH receptor cDNA. Journal of Biological Chemistry 267 23403-23408.

Nishikura K \& Murray JM 1987 Antisense RNA of proto-oncogene c-fos blocks renewed growth of quiescent $3 \mathrm{~T} 3$ cells. Molecular and Cellular Biology 7 639-649.

Oelgeschlager T 2002 Regulation of RNA polymerase II activity by CTD phosphorylation and cell cycle control. Journal of Cellular Physiology 190 160-169.

Piwien-Pilipuk G, Van Mater D, Ross SE, MacDougald OA \& Schwartz J 2001 Growth hormone regulates phosphorylation and function of C/EBP beta by modulating Akt and glycogen synthase kinase-3. Journal of Biological Chemistry 276 19664-19671.

Piwien-Pilipuk G, MacDougald OA \& Schwartz J 2002 Dual regulation of phosphorylation and dephosphorylation of $\mathrm{C} / \mathrm{EBP} \beta$ modulate its transcriptional activation and DNA binding in response to growth hormone. Journal of Biological Chemistry 277 44557-44565.

Piwien-Pilipuk G, Galigniana MD \& Schwartz J 2003 Subnuclear localization of $\mathrm{C} / \mathrm{EBP} \beta$ is regulated by growth hormone and dependent on MAPK Journal of Biological Chemistry 278 35668-35677.

Pokholok DK, Zeitlinger J, Hannett NM, Reynolds DB \& Young RA 2006 Activated signal transduction kinases frequently occupy target genes. Science 313 533-536.

Quinn PG 2002 Mechanisms of basal and kinase-inducible transcription activation by CREB. Progress in Nucleic Acid Research and Molecular Biology $\mathbf{7 2}$ 269-305.

Robertson LM, Kerppola TK, Vendrell M, Luk D, Smeyne RJ, Bocchiaro C, Morgan JI \& Curran T 1995 Regulation of c-fos expression in transgenic mice requires multiple interdependent transcription control elements. Neuron 14 241-252.

Rowland JE, Lichanska AM, Kerr LM, White M, d'Aniello EM, Maher SL, Brown R, Teasdale RD, Noakes PG \& Waters MJ 2005 In vivo analysis of growth hormone receptor signaling domains and their associated transcripts. Molecular and Cellular Biology 25 66-77.
Sadowski HB \& Gilman MZ 1993 Cell-free activation of a DNA-binding protein by epidermal growth factor. Nature 362 79-83.

Servillo G, Della Fazia MA \& Sassone-Corsi P 2002 Coupling cAMP signaling to transcription in the liver: pivotal role of CREB and CREM. Experimental Cell Research 275 143-154.

Shaywitz AJ \& Greenberg ME 1999 CREB: a stimulus-induced transcription factor activated by a diverse array of extracellular signals. Annual Review of Biochemistry 68 821-861.

Sheng M, Dougan ST, McFadden G \& Greenberg ME 1988 Calcium and growth factor pathways of c-fos transcriptional activation require distinct upstream regulatory sequences. Molecular and Cellular Biology 8 2787-2796.

Simone C, Forcales SV, Hill DA, Imbalzano AN, Latella L \& Puri PL 2004 p38 pathway targets SWI-SNF chromatin-remodelling complex to musclespecific loci. Nature Genetics 36 738-743.

Tollet-Egnell P, Parini P, Stahlberg N, Lonnstedt I, Lee NH, Rudling M, Flores-Morales A \& Norstedt G 2004 Growth hormone-mediated alteration of fuel metabolism in the aged rat as determined from transcript profiles. Physiological Genomics 16 261-267.

Treisman R 1994 Ternary complex factors: growth factor regulated transcriptional activators. Current Opinion in Genetics and Development 4 96-101.

Trigon S, Serizawa H, Conaway JW, Conaway RC, Jackson SP \& Morange M 1998 Characterization of the residues phosphorylated in vitro by different C-terminal domain kinases. Journal of Biological Chemistry 273 6769-6775.

VanderKuur J, Allevato G, Billestrup N, Norstedt G \& Carter-Su C 1995 Growth hormone-promoted tyrosyl phosphorylation of SHC proteins and SHC association with Grb2. Journal of Biological Chemistry 270 7587-7593.

Wilson HL, McFie PJ \& Roesler WJ 2002 Different transcription factor binding arrays modulate the cAMP responsivity of the phosphoenolpyruvate carboxykinase gene promoter. Journal of Biological Chemistry 277 43895-43902.

Winston LA \& Bertics PJ 1992 Growth hormone stimulates the tyrosine phosphorylation of 42- and 45-kDa ERK-related proteins. Journal of Biological Chemistry 267 4747-4751.

Yarwood SJ, Kilgour E \& Anderson NG 1998 Cyclic AMP potentiates growth hormone-dependent differentiation of 3T3-F442A preadipocytes: possible involvement of the transcription factor CREB. Molecular and Cellular Endocrinology 138 41-50.

Zhang X, Odom DT, Koo SH, Conkright MD, Canettieri G, Best J, Chen H, Jenner R, Herbolsheimer E, Jacobsen E et al. 2005 Genome-wide analysis of cAMP-response element binding protein occupancy, phosphorylation, and target gene activation in human tissues. PNAS 102 4459-4464.

Zhu T \& Lobie PE 2000 Janus kinase 2-dependent activation of p38 mitogenactivated protein kinase by growth hormone. Resultant transcriptional activation of ATF-2 and CHOP, cytoskeletal re-organization and mitogenesis. Journal of Biological Chemistry 275 2103-2114.

Received in final form 10 October 2007

Accepted 16 October 2007

Made available online as an Accepted Preprint 16 October 2007 